\title{
Evaluation of Farms' Sustainability According to Land Tenure in Mornag, Tunisia
}

\author{
Anissa Gara ${ }^{1,2 *}$, Mohamed Karim Aounallah ${ }^{1}$ and Dorra Ajabi ${ }^{1}$ \\ ${ }^{1}$ Institut National Agronomique de Tunisie, Avenue Charles Nicolle, Tunis, Tunisia; ${ }^{2}$ Laboratory of Rural \\ Economy at Institut National de Recherches Agronomiques de Tunisie, Avenue Hedi Karray, Tunis, Tunisia
}

*Corresponding author: anissa.gara@gmail.com

\begin{abstract}
In Tunisia the main objective of sustainable agriculture is to improve agricultural systems by creating more wealth and meeting the needs of the population without compromising those of future generations. It turned out that confusion and lack of clarity of ownership status of agricultural land would lead to instability in agricultural sustainability by having a negative impact on social and economic prosperity and environment preservation. Within this environmental concern, the current research constitutes an assessment of the level of sustainability of different farms in Tunisia where problems of land ownership still exist. The current research is based on the Farm Sustainability Indicators method (standing for: 'Indicateurs de durabilité des exploitations agricoles or IDEA). This case study employed IDEA method which provides operational content to compare the sustainability concept at the farm level, based on the factor of 'land tenure status'. In Tunisia, the lack of clear land ownership affects the output of agriculture that is why it is valuable to assess the impact of land properties status on farms' agricultural sustainability. Hence, we distinguished two groups of farms: Private Farms (PF) (inherited from father to son) and Farming Enhancement Corporation (FEC) (state's lands leased by farmers for many years). The results showed that land tenure has impact on farms sustainability. PF are more sustainable on both agro-ecological scale (49.2) and socio-territorial scale (48); compared to FEC (agro-ecological: 44.5 and socio-territorial: 46). PF favor integrated systems and the production of field crops and fodder crops and they attach greater importance to their employees' training.
\end{abstract}

Keywords: agriculture; land tenure; sustainability; Tunisia

Cite this as: Gara, A., Aounallah, M. K., \& Ajabi, D. (2021). Evaluation of Farms' Sustainability According to Land Tenure in Mornag, Tunisia. Caraka Tani: Journal of Sustainable Agriculture, 36(1), 45-57. doi: http://dx.doi.org/10.20961/carakatani.v36i1.43726

\section{INTRODUCTION}

Tunisia has experienced a significant reduction of poverty and improvement of social indicators since its independence in 1956 (Mkacher, 2013). Agricultural sector contributes to $10 \%$ of Growth Domestic Product (7,354 million dinars, 20122016 average) and represents $15 \%$ of national jobs (United Nations Economic Commission of Africa, 2014). In Tunisia, agriculture and fisheries sector occupies an important place in national economy and socio-politics due to its contribution to the achievement of national goals for food security, jobs opportunities and national incomes, regional balance and management of natural resources. Approximately $16 \%$ of Tunisia workforce engaged in the agricultural sector (Blom-Zandstra et al., 2017). However, the agricultural resource productivities in Tunisia are low compared to international or regional standards even in irrigated areas (Thabet et al., 2015). Tunisian agriculture has undergone great transformations from independence to the present day. From a geographical point of view, the sector

\footnotetext{
* Received for publication August 14, 2020

Accepted after corrections October 29, 2020
} 
has undergone a transformation, in particular by the strong urbanization and the sustained growth of the suburbs of the cities which have caused a significant loss of agricultural land. Losses of agricultural land following urbanization are estimated between 2,000 and 3,000 ha per year, despite the presence of legislation which controls or prohibits this practice (MoEE, 2013).

Agriculture that simultaneously takes into account these three dimensions can be qualified as "sustainable agriculture"; they are: the possibility to generate sufficient income for the household, applies agricultural practices that do not affect the environment, contributes to job creation and the social integration of farmers and transmissible (United Nations Economic Commission of Africa, 2014). Applied to the field of agriculture, the concept of sustainable development implies that the farmer's concerns are no longer relate solely to the objective of achieving economic profitability, but takes into account other dimensions, namely respect for the environment (conservation and good management of non-renewable resources, biodiversity of ecosystems and landscapes, optimization of production factors, etc.), social integration (promoting the integration of the farmer, integrating an ethical dimension, ensuring a certain social equity and well-being for the farmer) and the viability and transferability of the farm (the economic efficiency of the farming system, financial autonomy and dependence on aid, transferability of capital and transmission of knowledge) (Zahm et al., 2015).

The major challenge for policy makers in order to increase productivity in the agricultural sector in Tunisia is to improve the adoption rate of new innovations (Dhehibi et al., 2020). Understanding land users' livelihoods and their strategies is essential in order to adapt the prevention and adaptation policies and to ensure sustainable land management planning (Jendoubi et al., 2020). Also, a past study has highlighted that securing land tenure with legislation is essential in order to develop more productive agriculture (Singirankabo and Ertsen, 2020). After Tunisian revolution on 14 January 2011, farmers were facing negative effects such as decreasing farm subsidies, high production costs, increase in farmers' debts that reduction in reproduction capacity of the agriculture sector (Gana, 2012). Furthermore, the problem of sustainable agriculture in Tunisia has been addressed in several research works based on different determining aspects in agriculture and environment like the research conducted by Laajimi and Ben Nasr (2009). Tunisian agriculture is dominated by small and mediumsized farms (Jouili, 2009). Land fragmentation is essential (approximately increase $44 \%$ between 1961 and 2004) particularly in arable land, with an average of $5.257 \mathrm{ha}$; the average of fragmentation area is increased from 10 ha to 16 ha farm ${ }^{-1}$ by 1961 to 2004 . Approximately $75 \%$ of farmers have less than 10 ha (Gafrej, 2016; Ministry of Agriculture of Tunisia, 2016).

Land administration and land management systems in Northern Africa region, such as Tunisia, are characterized by the existence of various institutions and diversity of land tenures. A series of emerging policies has been developed and implemented according to the national needs and to the international regulations in order to meet the requirements of the new era (El-Ayachi et al., 2018a). Land tenure and land titles would have featured prominently in early agricultural economies but traditionally, land tenure security and agricultural productivity have been two separate areas of research. The link between land tenure security and agricultural productivity is therefore a relatively new subject (Singirankabo and Ertsen, 2020). In Tunisia, there are several land tenure statuses, as follow: 1) private properties known as family inheritance and 2) properties owned by rental contract with the state over a long period of time known as Farming Enhancement Corporation (FEC) (Akram et al., 2019). The organizational and economic mechanism of land ownership and land tenure is an integrity between land relations management system and economic influence methods of this system (Trukhachev et al., 2015).

The situation of agricultural land tenure in the study area similar as in many lands in Tunisia. It is characterized by remarkable fragmentations, which often prevents the application of good agricultural practices, especially in terms of conservation of resources and the use of quality agricultural equipment. Land reform experts claim that the main obstacle to increase agricultural output is the shortage of land and population pressure. However, it is not the shortage of land alone, which affects the output of agriculture; it is the structure of land tenure, the lack of clear land ownership and lack of improved agricultural technology and changing 
climatic conditions (Tenaw et al., 2009). The smaller the farm, the more difficult it is to invest in efficient and economical agricultural machineries and equipment. Accordingly, the agricultural sector in Tunisia includes several failures at the social level, which threaten the farms' sustainability.

Nowadays, it is a necessity to assess the sustainability of agricultural systems in the present world context. Various methods have been proposed to assess agricultural sustainability (Talukder et al., 2017). Several methods are proposed to assess agriculture sustainability for the environmental, social and economic aspects. The IDEA (Indicateurs de Durabilité des Exploitations Agricoles) method (farm sustainability indicators) has a remarkable potential to assess the strengths and weaknesses of production systems in order to analyze the intervention and commitment scenarios of the projects and public policies (Briquel et al., 2010). The aim of this study consisted of evaluating farms' agricultural sustainability with regard to a new factor of evaluation: the land tenure, that is to say, the land and legislative status of the appropriation of agricultural lands. The objective is the evaluation of farms' agricultural sustainability according the socioterritorial, economic and agro-ecological aspects. Thus, the comparison has concerned the two groups of farms: Private Farms (PF) properties: inherited from father to son and FEC: which is rental state land leased by farmers for a long period of time.

\section{MATERIALS AND METHOD}

The study site is the region of Mornag located at the delegation of Mornag in the Governorate of Ben Arous, at $10 \mathrm{~km}$ from the capital: Tunis, in the north-east of Tunisia. This region was chosen because it contains many FEC neighboring the PF. It is a region dominated by fruit-trees and cereals crops and characterized by a Mediterranean climate (Ministry of Environment and sustainable development of Tunisia, 2011). The mountains dominate the Mornag plain. Past study by Saqalli et al. (2020) revealed that olive trees are cropped intensively and threatened by the expansion of the nearby suburbs of Tunis due to the gap between new peri urban consumption practices in suburban Tunis and rural municipality budgets. Other agriculture- related threat highlights the gap between the vision of a preserved rural area and the agroindustrial reality.

There are two types of sampling methods: probability-sampling involves random selection and non-probability sampling. Probability sampling is any sampling scheme known as random sampling; whereas the non-probability sampling technique is based on judgement (Sharma, 2017). In this study, it was a nonrandom method (Taherdoost, 2020). A convenience sample is a type of non-probability sampling method where the samples were taken from easy-to-contact (or reach) groups. A survey was conducted in the Mornag region from March to April 2020.

A sub-sample comprised 15 FEC and $14 \mathrm{PF}$; hence, a total of 29 acceptable questionnaires were obtained from a total of 570 farmers in the region. According to the statistics of the regional office of agriculture of Ben Arous governorate related to the Ministry of Agriculture of Tunisia (2016); the obtained samples represented $5 \%$ of the total farmers in the region which is acceptable (Taherdoost, 2020). Due to the COVID-19 pandemic, farmers were reluctant and only a few of them participated in this study. Thus, a non-random method was used based on convenience sampling method. The samples consisted of FEC and PF at different sizes: small (less than $10 \mathrm{ha}$ ), medium (between 10 and 50) and large farmlands (more than $50 \mathrm{ha}$ ).

The questionnaire was performed in a manner to get the required data for the calculations procedures. These calculations were performed to obtain the values of all the indicators of the IDEA method used in the current study to reach the objective. The IDEA method has three scales that represent the dimensions of sustainability in a production system. They have the same weight which vary between 0 and 100 points. Each scale is subdivided into components with specific indicators which characterize a sustainable system. These components have maximum values of 33 (or 34 depending on the component); hence, each component is made up of several indicators.

The components bring together a total of 41 selected indicators. Each characterizes a practice in a sustainability scale and have an assigned and quantified score. The indicators seek to reflect the systemic dimension of the farm, but also each indicator aims to deliver a message 
in order to identify possible avenues of progress towards increased sustainability (Briquel et al, 2010). Each indicator has its own file to justify its relative weight and describe its method of calculation. The calculation method played an important role in assigning a given value of the IDEA method, which is far from being a simple.

The method assigns maximum (assigned ceiling value) or minimum (zero even if the sum of items is negative) scores for each indicator, to cap the total number of sustainability units relating to the scales studied. A farm's score for each of the three sustainability scales is the cumulative number of elementary sustainability units in that scale. The method does not allow the possibility of compensations between scales, which is why it leads to three joint evaluations which allow a systemic and more objective look at the farm and make it possible to compare farms whose practices are radically different. However, at the same scale and because the production systems are not unique, it is possible to compensate for certain technical weaknesses with options allowing better management and general organization of the farm.

In practice, for educational purposes, it is possible for the analysis of the scores obtained and to be able to carry out the comparison between operations (radars, histograms, etc.). The overall numerical value that will represent the sustainability of the operation is the value of the lowest scale. The advantage of the method is both to allow individual monitoring over time but also to highlight the differences in the sustainability of farms in the same agricultural region; the strengths as well as the limiting factors and how each could progress towards sustainability.

In other words, each scale has many components and each component is composed of many indicators. All these scales with their specific components and indicators are well described in the results. In fact, every indicator has a calculated score which stands on points. The summation of the indicators completes the scores or points of each component which is a certain value over 33 or 34 -depending on the component. Likewise, the summation of the total of scores (or points) of all the components give the total value of the scale over 100. All these calculations are made through a specific excel related to IDEA grid downloaded from.

That is to say, scores or points were assigned to each indicator for each farm and according to the calculation grid of the IDEA method (Briquel et al., 2010; Zahm et al., 2015). The excel and calculation grid were downloaded from internet following IDEA Version 4. Hence, the scores were inserted into the excel scoring table. The table provided a clear view of different values of the three scales and representing the obtained results in histograms and radars. These representations allowed comparisons between the scales, also between two distinct farms or between the different averages of farm groups. IDEA method was applied to assess the sustainability of family farms (Mariem et al., 2016); it was developed in France. It was chosen because it provides a holistic and integrated view of sustainability (Baccar et al., 2016). The IDEA method is structured around three sustainability scales: the agro-ecological sustainability scale, socio-territorial sustainability scale and economic sustainability scale (Biret et al., 2019). It identifies the practices or aspects that affect the sustainability of an operation, whether in positive or negative point of view; therefore guides the decision-making for operator and targeted effective modifications (Briquel et al., 2010).

\section{RESULTS AND DISCUSSION}

Land is a mean of livelihood and a source of wealth, tribal identity, social peace and a source of conflicts (Elhadary, 2010). Land in most of Africa (such as in Tunisia) is controlled under the customary tenure system (Yaro, 2010). Land tenure is a complex system, particularly in Northern Africa region. It is a combination of customary or religious law and origins in state. Thus, official legal systems have sought to entrench sovereignty overland due to the nation state's ascendancy over the past century and the abolition of customary law; which is the evolution of Shari'ah to deal with modern economic development needs (Rae, 2002; El-Ayachi et al., 2018b). Land tenure plays a major role in the agricultural sector's development and performance by influencing land ownership and its use (Dlamini and Masuku, 2011). Land tenure also affects farmers' perceptions toward agricultural land sustainability (Prasada and Masyhuri, 2020). 
The relationship between land property rights and agricultural investment is still contradictory (specifically in Africa) (Fenske, 2011). However, in more developed societies, the concept of land tenure security is implicit and backed up by long-standing institutions (Simbizi et al., 2014). Land tenure security in the form of certificates has increased land investment, such as improving land conservation management and increasing land productivity (Lanamana and Fatima, 2018). In this study, we analyzed a large group of farms and compared their sustainability according to the land tenure. Indeed, the large number of farms in our sample, with an area greater than 80 ha, had different land types, which were FEC and PF. The FECs are agricultural development firms where the land is state-owned and rented for many years. The people interested in renting these state farms shall submit their candidacies according to certain criteria and specifications to the agency to be considered in the Promotion of Agricultural Investments (related to Ministry of Agriculture).

The following is an assessment of the three scales elucidated to confer the different components and indicators of each scale.

\section{Agro-ecological scale}

According to United Nations Economic Commission of Africa (2014), within the spirit of the new Constitution, Tunisia has developed a new National Sustainable Development Strategy (2014-2020) which identifies nine challenges within the concerns of the green economy. The challenges are inclusive the establishment of sustainable consumption and production, sustainable natural resources management, balanced regional development and capacity building for adaptation to climate change, energy and renewable energy efficiency promotion, improvement of life quality, social equity and knowledge. One of the instruments for the economy and employment in the region is irrigated agriculture. However, this instrument is affected by multiple environmental and climatic risks and economic constraints (Lefort et al., 2018).

A National Strategy for the Green Economy (2016-2036) is being formulated based on an integrated approach that strengthens coherence between economic, social and environmental policies and a collaborative approach that involves all stakeholders of the society. It will include a bill on the green economy. This scale shall illustrate the degree of autonomy of farms regarding the good management and rational use of non-renewable resources and pollutiongenerating energies. The 17 indicators on this scale incorporate three areas of equal importance: the diversity of productions, the organization of space and agricultural practices. We will compare the averages obtained by the two groups in the three components of the agro-ecological scale: 'diversity', 'organization of space' and 'agricultural practices' to know the impact of the method of promoting on the durability of this scale.

According to Figure 1, we saw that PF have better averages in the two components 'space organization' and 'agricultural practices'; on the other hand, they are less sustainable than PF in the "diversity" component.

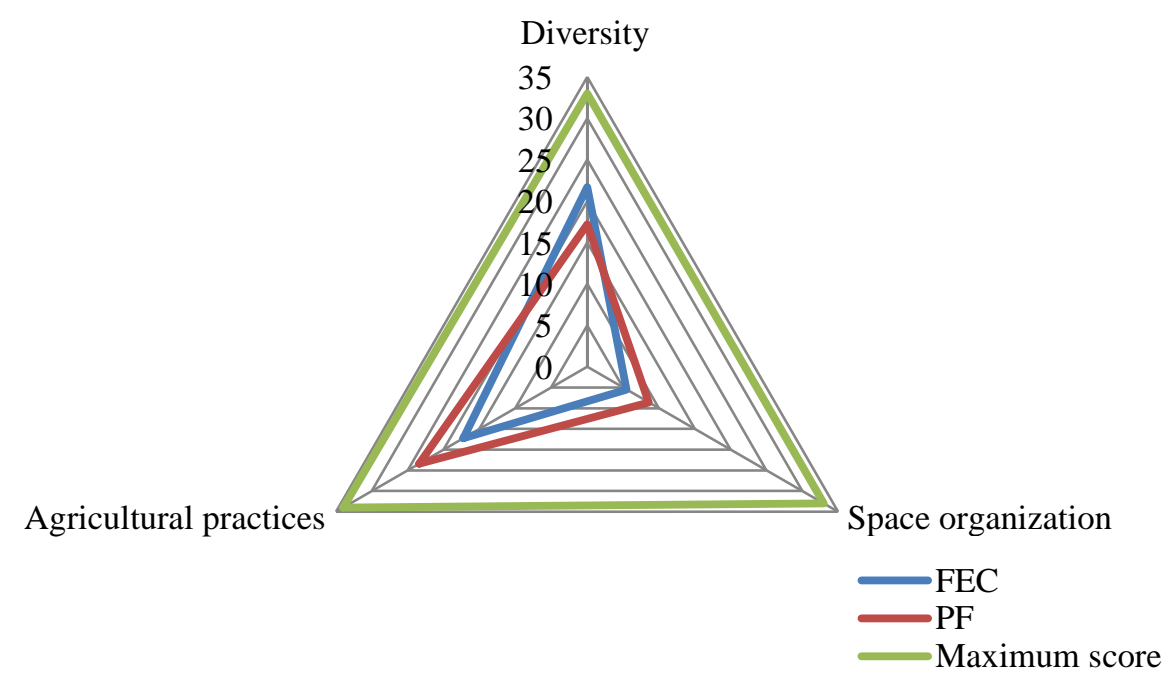

Figure 1. Averages of the components of the agro-ecological scale according to land tenure 
The diversity of productions has a huge impact on certain indicators that enhance the diversity of species and natural regulatory processes. Sustainable agriculture considers trees and permanent meadows to be important elements in ecological stability and the ecosystem's proper functioning (Supuka and Uhrin, 2016). In this component, the FEC have better averages although they do not include all the major crops; however, they greatly diversify the perennial species (olive trees, citrus fruits, peach trees, vineyards, wheat, barley, etc.). Indeed, the averages of indicators $\mathrm{A} 1$ and $\mathrm{A} 2$, about the diversity of annual and perennial species, are higher in FEC (Table 1). On the other hand, they obtain zero averages in indicators A3 and A4 about the practice of breeding; since none of the FEC surveyed practiced integrated agriculture. Therefore, we can see that although they are sanctioned by the lack of breeding on their farms, the FECs in the Mornag region have been able to compensate for the average of the "diversity" component with the variation of species and plant varieties.

Table 1. Results of the indicators of the 'diversity' component according to land tenure

\begin{tabular}{lccccc}
\hline & $\mathrm{A} 1(/ 14 \mathrm{pts})$ & $\mathrm{A} 2(/ 14 \mathrm{pts})$ & $\mathrm{A} 3(/ 14 \mathrm{pts})$ & $\mathrm{A} 4(/ 6 \mathrm{pts})$ & Total (/33pts) \\
\hline FEC & 10.0 & 11.75 & 0.0 & 0.0 & 21.75 \\
PF & 5.2 & 6.20 & 4.0 & 1.8 & 17.20 \\
\hline
\end{tabular}

Note: $\mathrm{FEC}=$ Farming Enhancement Corporation; $\mathrm{PF}=$ Private Farms

For the 'organization of space' component, both groups have low averages (Table 2). The FEC has a slightly lower average which could be explained by the fact that most FEC do not integrate breeding and do not practice rotations unlike some large private firms. Our sample's FECs mainly adopt arboricultural crops (olive trees, citrus fruits, vines, peaches, almonds, etc.) and very few field crops or fodder crops, with none that includes breeding. A farm can even be sanctioned by zero scores in indicators such as rotation (A5) which considers it necessary to integrate arable crops and natural surfaces to protect the soil resource and allow ecological interactions (wetlands, isolated tree, etc.). Other indicators such as the consideration of ecological regulation zones such as meadows or isolated trees (A8), or the contribution to the environmental issues of the territory by respecting a specification for the protection of certain zones (A9) have had very low or even zero averages for both groups. We then see that whatever the mode of marketing, farmers do not sufficiently consider the importance of adopting integrated, varied and reasoned agriculture; instead, above all, farmers seek immediate profitability from their productions.

Table 2. Results of the indicators of the 'organization of space' component according to land tenure

\begin{tabular}{lcccccccc}
\hline & $\begin{array}{c}\text { A5 } \\
(/ 8 \mathrm{pts})\end{array}$ & $\begin{array}{c}\text { A6 } \\
(/ 6 \mathrm{pts})\end{array}$ & $\begin{array}{c}\text { A7 } \\
(/ 5 \mathrm{pts})\end{array}$ & $\begin{array}{c}\text { A8 } \\
(/ 12 \mathrm{pts})\end{array}$ & $\begin{array}{c}\text { A9 } \\
(/ 4 \mathrm{pts})\end{array}$ & $\begin{array}{c}\text { A10 } \\
(/ 5 \mathrm{pts})\end{array}$ & $\begin{array}{c}\text { A11 } \\
(/ 3 \mathrm{pts})\end{array}$ & $\begin{array}{c}\text { Total } \\
\text { /33pts }\end{array}$ \\
\hline FEC & 1.5 & 0.25 & 1.25 & 2.5 & 0 & 0 & 0.0 & 5.5 \\
$\mathrm{PF}$ & 2.6 & 0.60 & 1.80 & 1.8 & 0 & 1 & 0.8 & 8.6 \\
\hline
\end{tabular}

Note: FEC = Farming Enhancement Corporation; PF = Private Farms

Other indicators related to the management of organic matter (A7), the valuation of space (A10) and the management of fodder areas (A11) are also very important in this component. We can see that the FEC have zero scores in the last three indicators related to breeding and development of space. These results showed us that regardless the method of promoting, the large farms in the Mornag region have weaknesses in the organization of their spaces, as well as in the integration of certain practices such as breeding and farming rotations which are conducive to sustainability. These farms should make better use of their resources and reorganize their plots in order to preserve the environment.

With regard to the 'agricultural practices' component (Table 3), the indicators which noted the inclusion of techniques and practices favorable to the environment showed that the FEC recorded lower scores, in particular because of the practices related to fertilization treatments 
(A12) and the massive use of pesticides (A14). Furthermore, most of the FECs surveyed included arboriculture and vines as their main speculation which were, very dependent on various chemical and fertilizer treatments, which explained the low average of these indicators.

Table 3. Results of the indicators of the 'agricultural practices' component according to land tenure

\begin{tabular}{lcccccccc}
\hline & $\begin{array}{c}\text { A12 } \\
(/ 8 \mathrm{pts})\end{array}$ & $\begin{array}{c}\text { A13 } \\
(/ 3 \mathrm{pts})\end{array}$ & $\begin{array}{c}\text { A14 } \\
(/ 13 \mathrm{pst})\end{array}$ & $\begin{array}{c}\text { A15 } \\
(/ 3 \mathrm{pts})\end{array}$ & $\begin{array}{c}\text { A16 } \\
(/ 5 \mathrm{pts})\end{array}$ & $\begin{array}{c}\text { A17 } \\
(/ 4 \mathrm{pts})\end{array}$ & $\begin{array}{c}\text { A18 } \\
(/ 10 \mathrm{pts})\end{array}$ & $\begin{array}{c}\text { Total } \\
(/ 34 \mathrm{pts})\end{array}$ \\
\hline FEC & 0.5 & 2.0 & 2.0 & 0 & 2.75 & 4 & 6.0 & 17.25 \\
$\mathrm{PF}$ & 2.8 & 1.8 & 6.2 & 0 & 2.00 & 4 & 6.6 & 23.40 \\
\hline
\end{tabular}

Note: FEC = Farming Enhancement Corporation; PF = Private Farms

On the other hand, PF have higher values in these indicators since many of their areas are occupied by large crops and permanent meadows that do not require as much chemical treatment and fertilizers. Therefore, we can deduce that field crops and livestock are more frequently integrated by large private companies. This delays the harmful effects on the environment thanks to the rotation, dry irrigation method and to the recovery of the organic matter. In addition, large private firms seem to invest more in production systems that save on inputs (saving water and fertilizers, etc.) and enhancing local resources (integration of a nursery for plants and seeds, use of greenhouses, etc.).

\section{Socio-territorial scale}

Socio territorial scale mainly implies the job creation and employment, services and the quality of lifestyle of the employees, beside the social involvement to territory. In Tunisia, several workshops have been organized recently to discuss the green economy. These workshops highlighted actions to be taken immediately such as: strengthening green economy legislation, evaluating the potential of green jobs and establishing a national green job map, matching training and qualification requirements and creating incentive mechanisms and programmes for green entrepreneurship. As an axis for the green job creation policy, the importance of regional development is also highlighted. Tunisia has set a short term goal to integrate green jobs in the new national employment strategy (20142017) which is soon to be adopted. A green jobs platform has been set up in the Ministry of Employment. As part of its green job programme, the ILO (International Labour Organization) estimated the number of green jobs in Tunisia is at 102,000 in 2010, mainly in water, waste, agriculture and services. An economic study conducted by the Millennium Institute in 2012 indicates that a green investment of $2 \%$ of GDP over 5 years could create about 300,000 direct jobs in Tunisia in areas such as construction, agriculture, energy and water, representing over 9\% of total employment (United Nations Economic Commission of Africa, 2014).

Regarding the socio-territorial scale, the comparison between the sustainability of the socio-territorial scale of PF and FEC allows us to determine whether the 'mode of asserting' factor affects agriculture's social and territorial dimension (Figure 2).

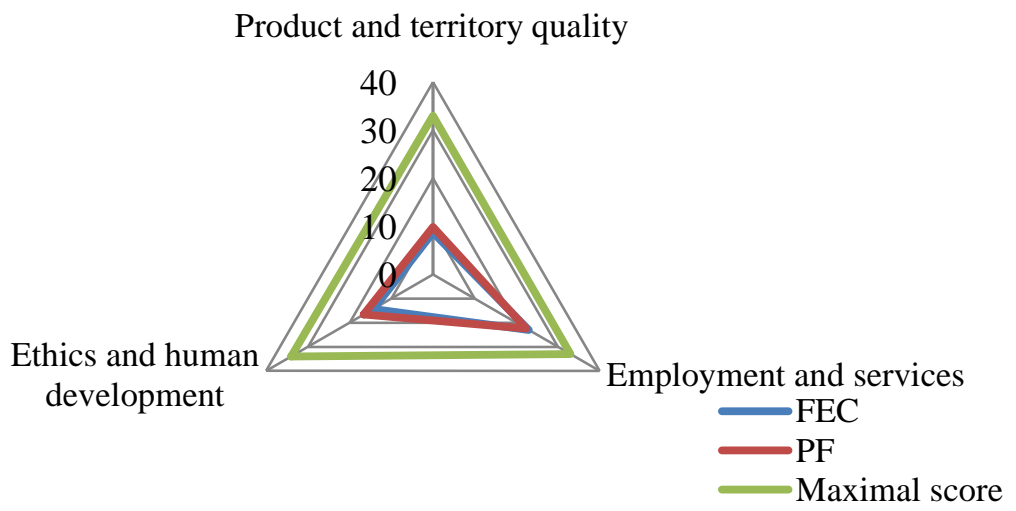

Figure 2. Comparison between the means of the components of the socio-economic scale according to land tenure 
Based on the graphic representation in radar (Figure 2), we can see that the differences between the three components of the socioterritorial scale are minimal. The sustainability of the two groups is similar in most of the indicators, especially those of the "employment and services" and "product and territory quality" component. The latter two components relate to indicators of product quality, good management of raw materials but also of waste, as well as social involvement and contribution to employment. Sustainable exploitation encourages the promotion of products, social equity and collective work to create the necessary links between agriculture and its territory (Akram et al., 2019).

According to Table 4, private companies slightly exceed the FEC in indicators B2 and B5 which respectively reflect the valuation of built heritage and social involvement. The FECs surveyed do not appear to be interested in landscaping and maintaining buildings and the surrounding areas, unlike private companies that invest a little more in infrastructure and landscapes. Likewise, private show-offs seem to be more involved in associations and technical structures, which allows them to keep pace with the developments in the sector and forge links with other representatives of the community and create a social dynamic.

Table 4. Average scores for the indicators of the 'product and terroir quality' component according to land tenure

\begin{tabular}{lcccccc}
\hline & B1 /10pts & B2/8pts & B3/5pts & B4/5pts & B5/6pts & Total (/33pts) \\
\hline FEC & 2.5 & 3.0 & 0.0 & 2.5 & 0.75 & 8.75 \\
PF & 1.4 & 4.3 & 0.4 & 2.4 & 1.40 & 9.90 \\
\hline
\end{tabular}

Note: FEC = Farming Enhancement Corporation; PF = Private Farms

The averages of the indicators of the "employment and services" component, shown in Table 5, show a slight variability which induces close final averages in this component. Indeed, the "private" group scores are slightly higher in indicator B6, representing the valuation by short supply chain, reflecting a distribution channel including at most two intermediaries between the consumer and the final product. Indeed, according to the surveys we found that these farms practice direct sales on the plot or at the local market in Mornag unlike the FECs who often sell their production on the vine or in the wholesale market which makes them more dependent on large markets. Regarding indicator B10, which reflects collective and networked work, the 'FEC' group scores are higher than those of PF. Indeed, the latter are more open to the concepts of the pooling and rental of equipment and the integration of networking in groups such as the GDA.

Table 5. Indicator scores for the 'employment and services' component according to land tenure

\begin{tabular}{lccccccc}
\hline & B6/7pts & B7/10pts & B8/5pts & B9/6pts & B10/5pts & B11/3pts & Total (/33pts) \\
\hline FEC & 5.25 & 3.0 & 3.0 & 6.0 & 2.75 & 3 & 23.0 \\
PF & 7.00 & 3.8 & 2.2 & 5.6 & 0.80 & 3 & 22.4 \\
\hline
\end{tabular}

Note: FEC $=$ Farming Enhancement Corporation; $\mathrm{PF}=$ Private Farms

In the "ethics and human development" component, which incorporates indicators related to training, the quality of life of employees and the integration of animal husbandry, the scores for $\mathrm{PF}$ are slightly higher (Table 6). The FEC group obtains the score of 'zero' at indicators B13 and B15 which respectively represent animal welfare and farmer work intensity. This is explained by the fact that the FEC do not include animal breeding in their productions and rely mainly on plant production on the one hand and on the other hand they have an overload of work specially at the harvest period given the diversity of cultures. Also, the FEC have better scores in indicators B14 and B17 related to training and the feeling of isolation of farmers. Indeed, the survey showed that FECs tend to be more involved in agricultural vocational training. This involves technical and theoretical training of staff, hosting paid trainees or groups of professionals and students, as well as collaboration with technical structures such as regional office of agricultural development related to Ministry of Agriculture, water resources and fisheries of Tunisia (El-ayachi et al., 2018a). 
Table 6. Indicator scores for the 'ethics and human development' component according to land tenure

\begin{tabular}{lcccccccc}
\hline & $\begin{array}{c}\text { B12 } \\
(/ 10 \mathrm{pts})\end{array}$ & $\begin{array}{c}\text { B13 } \\
(/ 3 \mathrm{pts})\end{array}$ & $\begin{array}{c}\text { B14 } \\
(/ 6 \mathrm{pts})\end{array}$ & $\begin{array}{c}\text { B15 } \\
(/ 7 \mathrm{pts})\end{array}$ & $\begin{array}{c}\text { B16 } \\
(/ 6 \mathrm{pts})\end{array}$ & $\begin{array}{c}\text { B17 } \\
(/ 3 \mathrm{pts})\end{array}$ & $\begin{array}{c}\text { B18 } \\
(/ 4 \mathrm{pts})\end{array}$ & $\begin{array}{c}\text { Total } \\
(/ 34 \mathrm{pts})\end{array}$ \\
\hline FEC & 1.25 & 0.0 & 4.25 & 0.0 & 3.75 & 2.25 & 2.75 & 14.25 \\
PF & 5.00 & 1.2 & 2.20 & 0.2 & 4.40 & 0.60 & 3.00 & 16.60 \\
\hline
\end{tabular}

Note: $\mathrm{FEC}=$ Farming Enhancement Corporation; $\mathrm{PF}=$ Private Farms

\section{Economic scale}

In the economic scale, the averages of the two groups come closer in the two components 'independence' and 'efficiency of the productive process', on the other hand they are clearly higher for the group of FEC in the components 'viability' and 'economic transferability' (Figure $3)$. In the component 'economic transferability' (C5), the FEC are distinguished by a good average value since it is a company which is leased for a specific and renewable period and whose succession from one generation to another is assured and protected by the state. Private companies have a fairly large capital and their succession depends on the number of family workers or partners whom are able to take over the capital in the event of cessation of activity.

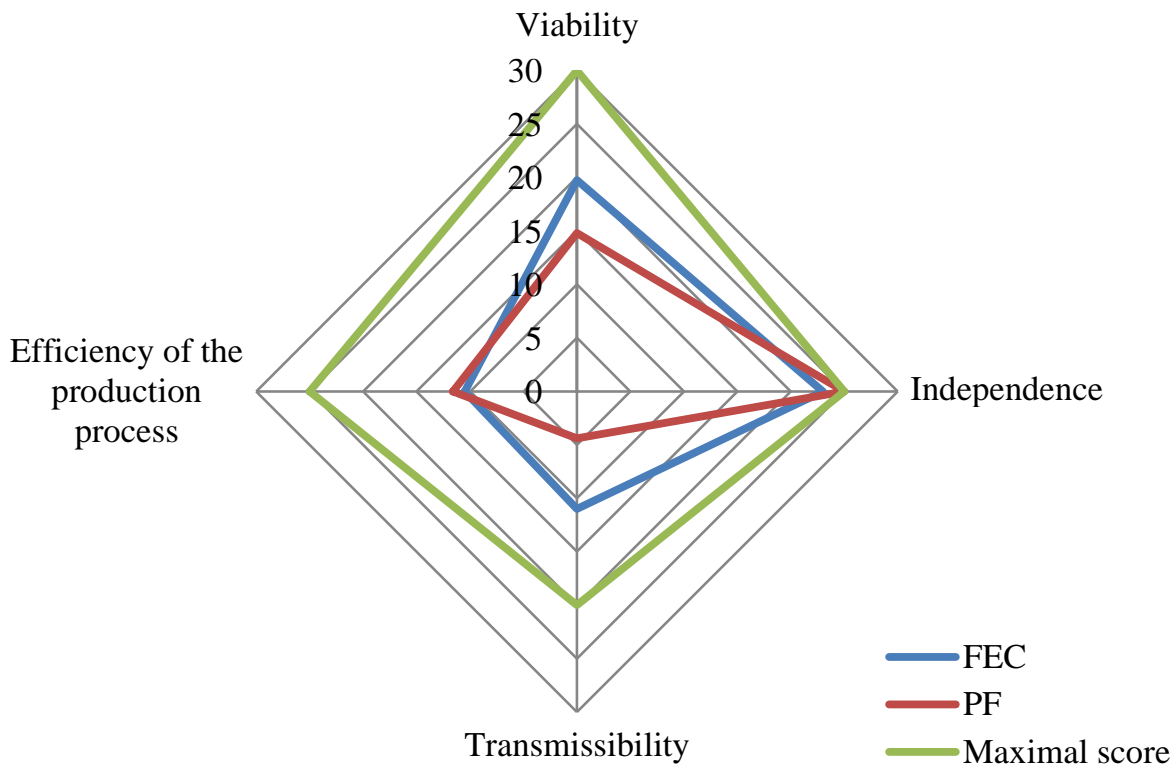

Figure 3. Comparison between the means of the components of the economic scale according to land tenure

Table 7 demonstrates that regarding the first component: 'viability', the first group records slightly higher averages mainly due to the indicator of 'economic viability' (C1) which was measured according to the current income per unit of non-wage labor. This could be explained by the fact that the FEC do not include family labor or associates and therefore the gross operating surplus is higher. For the second indicator C2: "Economic speciation rate", the two groups' averages are close. This indicator reflects the diversity of production on the farm and that of customers by analyzing the percentage of their contributions to total turnover. The more diversified the sources of turnover are, the less sensitive the operation will be to the risks and vagaries of the market and therefore more viable. Accordingly, Ciaian et al. (2018) affirmed that the fragmentation of land to many plots (privatization and heritage) affects the crop yield. The PF whose size are small tend to get extra agricultural activities. Multiple and diversified sources of income allow the family farms to have extra income outside agriculture. Labor, petty trade and construction works could be the sources of external income for these farms; partly to compensate for the lack of farm income (Jouili, 2009). 
Table 7. Ratings of economic scale indicators according to land tenure

\begin{tabular}{lccccccccc}
\hline & \multicolumn{3}{c}{ Economic viability } & \multicolumn{3}{c}{ Independency } & \multicolumn{3}{c}{ Transmissibility } \\
\cline { 2 - 9 } & $\mathrm{C} 1$ & $\mathrm{C} 2$ & Total & $\mathrm{C} 3$ & $\mathrm{C} 1$ & $\mathrm{C} 2$ & Total & $\mathrm{C} 3$ & $\mathrm{C} 1$ \\
& $/ 20 \mathrm{pts}$ & $/ 10 \mathrm{pts}$ & $/ 30$ & $/ 15 \mathrm{pts}$ & $/ 20 \mathrm{pts}$ & $/ 10 \mathrm{pts}$ & $/ 30$ & $/ 15 \mathrm{pts}$ & $/ 20 \mathrm{pts}$ \\
\cline { 2 - 10 } FEC & 15.25 & 4.5 & 19.75 & 13.5 & 15.25 & 4.5 & 19.75 & 13.5 & 15.25 \\
$\mathrm{PF}$ & 10.80 & 4.0 & 14.80 & 15.0 & 10.80 & 4.0 & 14.80 & 15.0 & 10.80 \\
\hline
\end{tabular}

Note: FEC $=$ Farming Enhancement Corporation; $\mathrm{PF}=$ Private Farms

The scores for the 'independence' component are similar between the two groups. PF have higher averages in the financial autonomy' indicator (C3) because they are less dependent on agricultural credit and have a respectable margin of maneuver between annuities and gross operating surplus. They also have the highest score in the 'aid sensitivity' component (C4), which tends to detach private companies from agricultural support systems and aid.

As for the "transmissibility" (C5) indicator, the best average is attributed to the group of FEC. This indicator reflects the importance of the succession of capital from one generation to another or in the event of the manager's departure. Concerning the state's land, the takeover of capital is effectively guaranteed by the state since the holdings are managed in the form of fixed-term rentals. In the event of cessation of activity, the takeover by a new promoter is provided by the state's institutions (APAI, etc.). On the other hand, large PF with significant capital must ensure the transition and sustainability of the activity by integrating family labor and associates, which is not always the case in our investigation samples.

Finally, component C6: "Efficiency" concerns about the 'efficiency of the production process' and the ability to ensure high production and generate added value while optimizing the use of resources. The score for PF is slightly higher, demonstrating better management of inputs relating to intermediate, operational and processing costs and better technological performance. Indeed, we have seen that large firms were more attracted by technological innovation and investment in production processes that allow them an optimal ratio between inputs and output and therefore better production efficiency. Land registration clarification would realize land tenure security and allow farmers to better use of their land plots, to get loans from the bank and invest in new farming systems and technology in order to increase the yield at a lower cost of production. Holding legal proof of land rights is claimed to stimulate farmers' initiative to invest in a more productive agriculture (Singirankabo and Ertsen, 2020).

Figure 4 illustrates the final synthesis of three scales of sustainability based on the calculation of indicators and components obtained in the two groups of farms. However, the averages of the indicators and components vary considerably from group to group, the overall averages of the three scales are approximate.

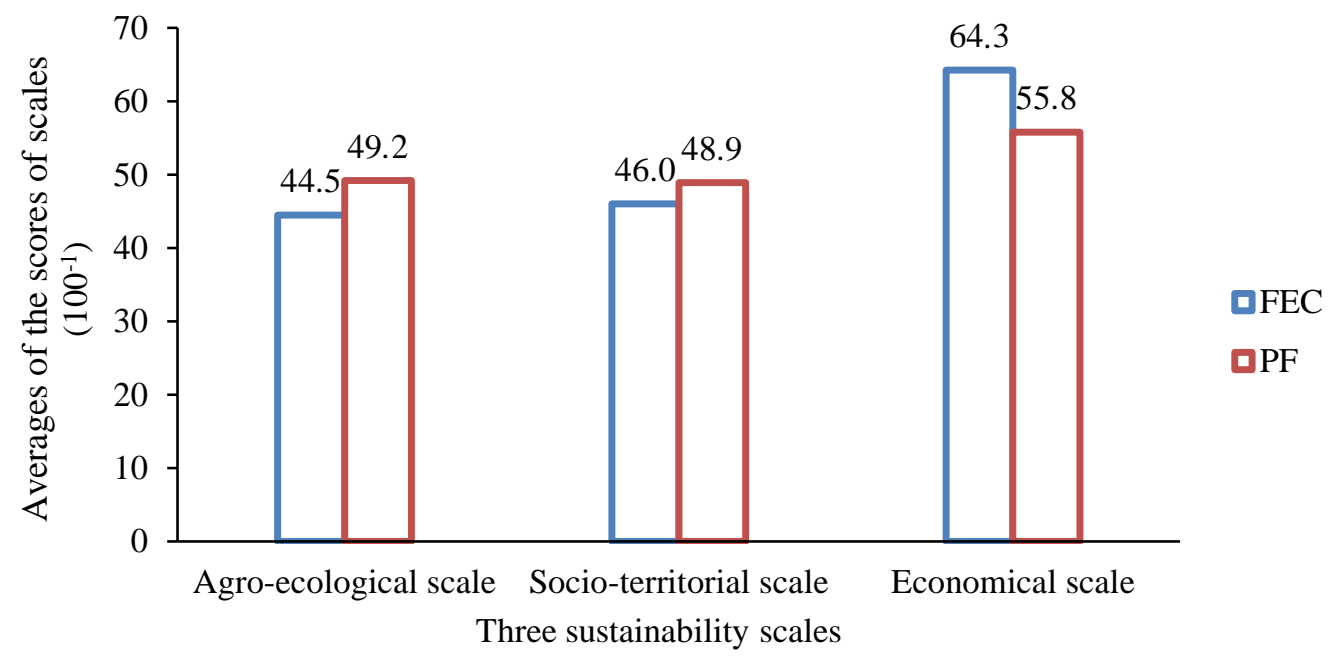

Figure 4. Representation of the scores averages of the three scales according to land tenure 


\section{CONCLUSIONS}

We can conclude that the impact of land tenure factor is different from one scale to another. Indeed, PF are more sustainable in both scales: agro-ecological because they favor integrated systems and the production of field crops and fodder crops and socio-territorial because they give more importance to employees' training aspect and reception of interns. However, PF are less sustainable on the economic scale mainly because of the "transferability" indicator for which the FEC recorded the best averages thanks to the transferability of the capital which is managed and guaranteed by the state. In other words, results derived from the comparisons confirmed that PF are more sustainable than 'FECs' on both scales: agro-ecological and socioterritorial and FECs are better for the economic scale since FEC are large sized farmlands while $\mathrm{PF}$ have a panel of size (small, medium and large area) and are usually smaller than FEC. Subsequently, we can conclude that the land tenure has repercussions on land size and consequently on farms agricultural sustainability.

\section{REFERENCES}

Akram, N., Akram, M. W., Wang, H., \& Mehmood, A. (2019). Does land tenure systems affect sustainable agricultural development? Sustainability (Switzerland), 11(14), 3925. https://doi.org/10.3390/su111 43925

Baccar, M., Bouaziz, A., Dugue, P., Gafsi, M., \& Le Gal, P. Y. (2016). Assessing family farm sustainability using the IDEA method in the Saiis plain (Morocco). Conference: IFSA: Social and technological transformation of farming systems: Diverging and converging pathways at: Newport, UK. Retrieved from http://ifsa.boku.ac.at/cms/fileadmin/IFSA201 6/IFSA2016_WS22_Baccar.pdf

Biret, C., Buttard, C., Farny, M., Lisbona, D., Janekarnkij, P., Barbier, J. M., \& Chambon, B. (2019). Assessing sustainability of different forms of farm organization: Adaptation of idea method to rubber family farms in Thailand. Biotechnology, Agronomy and Society and Environment, 23(2), 74-87. https://doi.org/ $10.25518 / 1780-4507.17622$

Blom-Zandstra, G., Axmann, H., \& Heesmans, H.
(2017). Needs assessment of the agriculture in North-West Tunisia ; Evaluation of the key priorities for agricultural resilience. Wageningen Research, Report, WPR-720, pp. 30. https://doi.org/10.18174/444766

Briquel, V., Vilain, L., Bourdais, J. L., Girardin, P., Mouchet, C., \& Viaux, P. (2010). La méthode IDEA (indicateurs de durabilité des exploitations agricoles): une démarche pédagogique. In Ingénieries eau-agricultureterritoires (Issue 25), pp. 29-39. Retrieved from https://hal.archives-ouvertes.fr/hal-0046 4508

Ciaian, P., Guri, F., Rajcaniova, M., Drabik, D., \& Paloma, S. G. (2018). Land fragmentation and production diversification: A case study from rural Albania. Land Use Policy, 76, 589-599. https://doi.org/10.1016/j.landusepol.2018.02.0 39

Dhehibi, B., Rudiger, U., Moyo, H. P., \& Dhraief, M. Z. (2020). Agricultural technology transfer preferences of smallholder farmers in Tunisia's arid regions. Sustainability (Switzerland), 12(1), 421. https://doi.org/ 10.3390/SU12010421

Dlamini, D. D., \& Masuku, M. B. (2011). Land tenure and land productivity: A case of maize production in Swaziland. Asian Journal of Agricultural Sciences, 3(4), 301-307. Retrieved from https://maxwellsci.com/jp/ abstract.php?jid=AJAS\&no $=124 \&$ abs $=08$

El-Ayachi, M., Bouramdane, L., \& Tine, M. G. (2018a). The land tenure systems in Northern Africa: challenges and opportunities. African Journal on Land Policy and Geospatial Sciences, 1(1), 21-32. https://doi.org/ 10.48346/IMIST.PRSM/ajlp-gs.v1i1.12403

El-Ayachi, M., Bouramdane, L., \& Tine, M. G. (2018b). The Northern Africa land tenure: Challenges and opportunities of sustainable development. Pp. 1-9. Retrieved from https:// www.uneca.org/sites/default/files/uploadeddocuments/LPI/CLPA_2017/Presentations/no rthern_africa_land_tenure.pdf

Elhadary, Y. A. E. (2010). Challenges facing land tenure system in relation to pastoral livelihood security in Gedarif State, Eastern Sudan. Journal of Geography and Regional Planning, 3(9), 208-218. Retrieved from https:// 
academicjournals.org/journal/JGRP/article-fu 11-text-pdf/2E809A340598

Fenske, J. (2011). Land tenure and investment incentives: Evidence from West Africa. Journal of Development Economics, 95(2), 137-156. https://doi.org/10.1016/j.jdeveco.20 10.05 .001

Gafrej, R. (2016). Avec le changement climatique, quel avenir de l'agriculture en Tunisie?. Watch Letter $\mathrm{n}^{\circ} 37$ - Septembre 2016. Retrieved from https://www.ciheam.org/uploa ds/attachments/277/033_Gafrej_WL_37.pdf

Gana, A. (2012). The rural and agricultural roots of the Tunisian Revolution: When food security matters. International Journal of Sociology of Agriculture and Food, 19(2), 201-213. Retrieved from https://halshs. archives-ouvertes.fr/halshs-01165135

Jendoubi, D., Hossain, M. S., Giger, M., Tomićević-Dubljević, J., Ouessar, M., Liniger, H., \& Speranza, C. I. (2020). Local livelihoods and land users' perceptions of land degradation in northwest Tunisia. Environmental Development, 33, 100507. https://doi.org/10.1016/j.envdev.2020.100507

Jouili, M. (2009). Tunisian agriculture : Are small farms doomed to disappear? Small Farms: Decline or Persistence', European Association of Agricultural Economists; International Association of Agricultural Economists, 1-15. Retrieved from https://hal.archives-ouvertes. fr/hal-01180353

Laajimi, A., \& Ben Nasr, J. (2009). Appréciation et comparaison de la durabilité des exploitations agricoles biologiques et conventionnelles en Tunisie: Cas de l'oléiculture dans la région de Sfax. New Medit, 8(1), 10-19. Retrieved from https:// newmedit.iamb.it/edizioni_new_medit,229,22 9,2009,85,243,appreciation-et-comparaison-d e-la-durabilite-des-exploitations-agricoles-bio logiques-et-conventionnelles-en-tunisie-:-casde-loleiculture-dans-la-region-de-sfax.htm

Lanamana, W., \& Fatima, I. (2018). Effects of different land status on conservation land and income of upland rice farming in Mausambi Village, Maurole Subdistrict, Ende Regency. Caraka Tani: Journal of Sustainable Agriculture, 33(2), 126-135. https://doi.org/ 10.20961/carakatani.v33i2.21704

Lefort, S., Aumont, O., Bopp, L., Arsouze, T., Gehlen, M., \& Maury, O. (2015). Spatial and body-size dependent response of marine pelagic communities to projected global climate change. Global Change Biology, 21, 154-164. https://doi.org/10.1111/gcb.12679

Mariem, B., Ahmed, B., Patrick, D., Mohamed, G., \& Pierre-Yves, L. G. (2016). Assessing family farm sustainability using the IDEA method in the Saiis plain (Morocco). Social and Technological Transformation of Farming Systems: Diverging and Converging Pathways. Newport: IFSA, 11 p. European IFSA Symposium. 12, Newport, Royaume-Uni, 12 July 2016/15 July 2016. Retrieved from https://agritrop.cirad.fr/582649/

MAT (Ministry of Agriculture of Tunisia). (2016). Référentiel du développement agricole durable en Tunisie. 60. Retrieved from https://www.slideshare.net/Agridurable/rfrenti el-du-dveloppement-agricole-durable-en-tunis ie-79966376

Ministry of Environment and Sustainable Development of Tunisia. (2011). National Strategy for Sustainable Development (SNDD), Final document. December 2011. Republic of Tunisia

Mkacher, S. B. H. M. (2013). Explaining rural poverty persistence in Tunisia from the perspective of path dependence theory. The 4th International Conference of the African Association of Agricultural Economists, 1-13. Retrieved from https://ageconsearch.umn.edu/ record/161642/files/Safa\%20Ben\%20Hadj\%2 0Mbarek\%20Mkacher.pdf

MoEE. (2013). Ministry of Equipment and Environment: Seconde Communication Nationale de la Tunisie à la Convention Cadre des Nations Unies sur les Changements Climatiques. 1-174. Retrieved from http:// www.anme.tn/sites/default/files/deuxieme_co mmunication_nationale_de_la_tunisie_a_la_c cnucc.pdf

Prasada, I. Y., \& Masyhuri, M. (2020). Factors affecting farmers' perception toward agricultural land sustainability in peri-urban areas of Pekalongan City. Caraka Tani: Journal of Sustainable Agriculture, 35(2), 
203-212. https://doi.org/10.20961/carakatani. v35i2.31918

Rae, J. (2002). An overview of land tenure in the Near East region (Vol. 1). FAO. Retrieved from http://www.fao.org/3/a-aq202e.pdf

Saqalli, M., Hamrita, A., Maestripieri, N., Boussetta, A., Rejeb, H., Mata Olmo, R., Kassouk, Z., Belem, M., Saenz, M., \& Mouri, H. (2020). "Not seen, not considered": mapping local perception of environmental risks in the Plain of Mornag and Jebel Ressass (Tunisia). Euro-Mediterranean Journal for Environmental Integration, 5(2), 1-14. https:// doi.org/10.1007/s41207-020-00166-y

Sharma, G. (2017). Pros and cons of different sampling techniques. International Journal of Applied Research, 3(7), 749-752. Retrieved from https://www.allresearchjournal.com/arch ives/2017/vol3issue7/PartK/3-7-69-542.pdf

Simbizi, M. C. D., Bennett, R. M., \& Zevenbergen, J. (2014). Land tenure security: Revisiting and refining the concept for SubSaharan Africa's rural poor. Land Use Policy, 36, 231-238. https://doi.org/10.1016/j.landuse pol.2013.08.006

Singirankabo, U. A., \& Ertsen, M. W. (2020). Relations between land tenure security and agricultural productivity: Exploring the effect of land registration. Land, 9(5), 138. https:// doi.org/10.3390/LAND9050138

Supuka, J., \& Uhrin, P. (2016). Share of scattered woody vegetation in landscape ecological stability and agriculture sustainability. Folia Oecologica, 43(2), 193-203. Retrieved from https://www.researchgate.net/publication/318 909628_Share_of_scattered_woody_vegetatio n_in_landscape_ecological_stability_and_agri culture_sustainability

Taherdoost, H. (2020). Sampling methods in research methodology; How to choose a sampling technique for research. International Journal of Academic Research in Management (IJARM), 5(2), 18-27. Retrieved from https://hal.archives-ouvertes.fr/hal-02546796/ document

Talukder, B., Blay-palmer, A., Hipel, K. W., \& Gary, W. (2017). Elimination method of Multi-Criteria Decision Analysis (MCDA): A simple methodological approach for assessing agricultural sustainability. Sustainability, 9(2), 287. https://doi.org/10.3390/su9020287

Tenaw, S., Islam, K. M. Z., \& Parviainen, T. (2009). Effects of land tenure and property rights on agricultural productivity in Ethiopia, Namibia and Bangladesh. University of Helsinki, Department of Economics and Management, Discussion Papers no. 33. Retrieved from http://www.fao.org/fileadmin/ user_upload/fsn/docs/HLPE/Discussion_Pape r_33.pdf

Thabet, B., Dhehibi, B., Kassam, S., \& AwHassan, A. (2015). Good intensions and hard realities: achievements and challenges in agricultural extension systems in Tunisia. International Journal of Agricultural Extension, 3(3), 209-216. Retrieved from https://esciencepress.net/journals/index.php/IJ AE/article/download/1330/726

Trukhachev, V., Ivolga, A., \& Lescheva, M. (2015). Enhancement of land tenure relations as a factor of sustainable agricultural development: Case of Stavropol Krai, Russia. Sustainability (Switzerland), 7(1), 164-179. https://doi.org/10.3390/su7010164

United Nations Economic Commission of Africa. (2014). The green economy in Tunisia: an implementation tool of the new sustainable development strategy (2014-2020). Retrieved from https://www.uneca.org/sites/default/files /uploaded-documents/SROs/NA/AHEGM-IS DGE/egm_ge-_tunisa_eng.pdf

Yaro, J. A. (2010). Customary tenure systems under siege: Contemporary access to land in Northern Ghana. GeoJournal, 75(2), 199-214. https://doi.org/10.1007/s10708-009-9301-x

Zahm, F., Alonso Ugaglia, A., Boureau, H., Del'homme, B., Barbier, J. M., Gasselin, P., Gafsi, M., Guichard, L., Loyce, C., Manneville, V., Menet A., \& Redlingshofer, B. (2015). Agriculture et exploitation agricole durables: état de l'art et proposition de définitions revisitées à l'aune des valeurs, des propriétés et des frontières de la durabilité en agriculture. Innovations Agronomiques, 46, 105-125. Retrieved from https://hal.archivesouvertes.fr/hal-01585176/document 